\title{
Not too Well-known "Predecessors" of C. R. Rogers's Humanistic Pedagogy (J. A. Comenius, J. I. Felbiger, J. F. Herbart, O. Chlup) ${ }^{*}$
}

\author{
Radim Štěrba \\ Department of Civics, Faculty of Education, Masaryk University Brno, the Czech Republic
}

Copyright $\subset 2018$ by authors, all rights reserved. Authors agree that this article remains permanently open access under the terms of the Creative Commons Attribution License 4.0 International License

\begin{abstract}
The paper deals with the analysis of the works of selected pedagogical thinkers in relation to the humanistic pedagogy of C.R. Rogers. The aim of the paper is to identify the components of humanistic pedagogy - Person Centred Education (PCE) in pedagogical theories that were created prior to the PCE. Based on the content analysis, we tried to identify the central components of PCE - empathy, authenticity and acceptance in pedagogical concepts of significant pedagogical thinkers. We focused on selected pedagogical thinkers who lived in Central European space from the first half of the 17th century until the first half of the 20th century. In particular, such thinkers were selected who were ideally close to the PCE bases influenced by European humanism - J. A. Comenius (Komenský) and his lesser known successor J. I. Felbiger, German thinker J. F. Herbart and later O. Chlup influenced by pedocentrism. The above-mentioned authors dealt with the subject of teacher empathy, at Comenius we even have the technique of active listening, and we also find authenticity and acceptance. We can say that these central components of PCE had been used in pedagogical theories to varying degrees before the PCE was established. In addition to enriching and modifying contemporary pedagogical theory, the article also aims inspire interest in pedagogical thinkers of past centuries who have dealt with similar problems in our theories that we are dealing with today. Thanks to this thematically defined reflection of the mentioned pedagogical theories, we can get inspirational insights into some of the problems of contemporary pedagogical theory and practice.
\end{abstract}

Keywords Humanistic Pedagogy, Predecessor, Empathy, Active Listening

\section{Introduction}

Acceptance, authenticity and empathy are the key pillars of the therapist's approach to the client within the psychotherapeutic direction, which was called a person centered approach (PCA, see [1]). Since the 1960s, the PCA has gradually moved into education and transformed into a human-oriented education $[1,2]$. According to these widespread facts, teacher's approach to pupils, based on Acceptance, Authenticity and Empathy (AAE), originated first in the mentioned psycho-therapeutic direction (PCA) to be later used in the school environment within the PCE. We believe that this widespread knowledge is at least inaccurate. In our article we will try to prove that these components of access to the other (AAE) do not originate in Rogers's PCE but have been more or less defined much earlier within the framework of Central European pedagogy. We will try to prove that some of the pedagogic theoreticians in their concepts discovered a few centuries earlier the Rogers's theoretical concept, which then had to be "re-discovered". ${ }^{1}$

To indicate the direction that incorporated into the pedagogical contexts the ideas of humanistic psychology, especially Maslow and Rogers, can be used the term humanistic pedagogy [3]. However, this is not the only name of this direction. Bertrand incorporated Rogers's concept into the stream of personalistic educational theories. The common central idea for these theories is to focus on the personality of the pupil, who is to be the starting point of the educational process. He was inspired

1 For this reason, the "re-discovered" author has not found any inspiration from these predecessors in the PCA literature. Based on a literature search, it was found that there are also no more comprehensive Czech pedagogical works that would be deeper into the subject of teacher empathy. Mentions of its importance can be found in studies dealing with the topic of teacher competencies - the social competence of the teacher, see R. Sterrba in summary. Empathy as part of the teacher's social competence, Quality Reflection in Doctoral Pedagogical Research: Reviewed Proceedings of the Doctoral Conference held on 21 May 2012 in Prague, Prague, pp. 9-20, 2012. 
by pedocentric-oriented theories of the early twentieth century (Bertrand mentions Montessori and Neill, see [4]). Bertrand then included "Rogers's pedagogy" in so-called non-direct education within pedocentric theories, [4]. This points to the original designation of Rogers's therapeutic concept, the rejection of the traditional directive approach to the patient. Rogers's approach was based on a facilitating therapist who is only a guide and support provider for self-discovery of the client [5]. As Singler notes, Rogers put this non-directivity into school practice and named it "a pupil-centered approach - PCE," see [6].

In this approach, the teacher should trust the pupil's natural ability to learn and explore. He should support the natural tendency of the positive direction of human being, who seeks to realize his or her inner potential (his or her potentiality). Realizing potencialities then means moving towards full humanity. To developing the potentiality, Rogers added that an individual tends not to develop all his potentiality, especially destructive potentiality (assumptions to self-defeating). These are only updated for the organism under unfavorable conditions [7].

The aim of the teacher in school teaching is to facilitate, to support what Rogers called the so-called significant learning (elsewhere, also significant learning, experience learning). It is "learning that is more than just accumulation of facts. It is a learning that brings about a change in man's behavior ... in his attitudes and personality." [8].

According to Rogers, the content of learning (here in particular learning of facts) is rather second-class learning. The pupil should learn mainly the proces of learning. In order to realize this important learning, appropriate conditions must be created. Rogers noted that support for significant learning is not related to curricula, academic knowledge, audio-visual aids etc. Supporting this learning depends mainly on the character of attitudes that are in the relationship between the teacher and his or her pupils. The basis is the positive relationship between the teacher and his or her pupil based on mutual understanding and respect [9].

Here, teacher's empathy, understanding, associated with active listening takes its central place. An integral part of empathy is also the expression, verbalisation of empathy (so-called active listening). Only then the expressed empathy can be therapeutically effective when the client realizes that the other side really understands it. Of course, empathy also manifests itself without words, in mimics, tone of voice and gesture in which we express our understanding [2].

This is associated with teacher's personality, that is, by his or her congruence, acceptance, and empathy (AAE). In this context, however, it is necessary to assume that the pupil should at least partially perceive these three aspects authenticity, acceptance, empathy (AAE). In the case of empathy, therefore, it is mainly expressed empathy in interpersonal communication - active listening [8].
The teacher, with the help of AAE, has to lead the pupil to discover his or her inner potential, self-realization and self-actualization.

Rogers tried to describe the congruent aspects of the teacher. An authentic (congruent) teacher is the one who accepts his or her own real feelings, such as experiencing enthusiasm at his or her favorite subjects or topics, boredom on subjects / topics less favourite [8]. Let us add that congruence is associated with self-empathy, when an individual can listen to himself or herself, to his or her actual experience.

However, authenticity should always be appropriate to the situation. Of course, the teacher should always encourage pupils' interest rather than discourage them in any way. In relation to Rogers's example, even according to his conception, the congruence should be appropriate to the situation. He or she certainly should not hide his or her authentic enthusiasm in the discussed topic. However, with regard to boredom, we think he or she should not artificially pretend to be enthusiastic about something he or she does not like (it certainly would not be authentic). He or she should not also express boredom by his attitude, expression. The teacher should be aware that the themes are needed and interesting in some ways. He or she should strive to go deep and find something interesting for himself or herself and for pupils [10].

Upon acceptance, the teacher should try to accept the pupil as he or she is and should try to understand his or her feelings. In order for this to happen, it is necessary to create such an environment. An environment in which these feelings could be openly expressed without fear [8]. Understanding means understanding the pupil's interior. Here Rogers pointed out that it is not about evaluating understanding, i. e. the understanding that is associated with the assessment attitude. This empathic understanding, which must be expressed in order for the pupil to perceive it [9]. Thus, empathic teacher not only empathize with his or her pupils, but also expresses his or her understanding in communication.

In addition to his or her empathic approach to the pupil, the teacher, as we have already said, is also congruent and accepting. On the basis of this complex approach, a positive atmosphere of mutual trust is created, in which pupil's self-development can take place. In this positive climate, the pupils will be themselves, they will be happy to learn.

From this it is evident that Rogers placed a great emphasis on teacher, especially his or her ability of empathy, authenticity and acceptance, which are a prerequisite for creating the corresponding atmosphere in the classroom [3].

\section{Objectives}

The main objective is to identify the elements of 
humanistic pedagogy - PCE, empathy, acceptance and authenticity of the teacher, in selected important pedagogical theories created before the establishment of the PCE. On this basis, we can then provide a more comprehensive overview of empathy, acceptance, and authenticity as specific components of the teacher's approach, also about their development and position within the given pedagogical concept. Therefore, central research questions for which we will seek the answer are:

- Are the teacher's empathy, acceptance and authenticity discussed in selected pedagogical concepts?

- What is the position of teacher's empathy, acceptance and authenticity in selected pedagogical theories?

- How did their concepts of these theories evolve further?

\section{Methods}

The basic methodological basis, based on the nature of the studied material, is content analysis of documents, which is a standard approach in quantitative and qualitative research [11, 12]. According to Hendl, everything written can be considered as a document, ie books, newspaper articles, etc. The advantage of this approach is that the data contained in the documents is not exposed to the sources of errors that arise from other research methods (observation, interview - the presence of a researcher influencing the object being investigated) where the subjectivity of the researcher also does not play a role in relation to the information contained in the document. When analyzing text documents, the researcher cannot intervene in the content of these documents, nor change them. Thus, the possibility of distortion is limited, and anyone who works with the material has the same possibilities [12]. According to Mayring [11, 12, 13] the processing process consists of several phases:

- defining the research question,

- determining the nature of the document searching for relevant documents,

- external and internal review of documents,

- analysis of document interpretation aimed at finding answers to research questions.

\subsection{Selection of Pedagogical Concepts}

When choosing pedagogical concepts, we had two initial criteria. The first was regional / local, ie. pedagogical concepts were created or, if necessary, had a major influence on the development of pedagogical thinking in the Central European space (today's Czech Republic). This criterion was based on the previous findings (see note 1) and was to find out whether similar topics (empathy, acceptance, authenticity of the teacher (AAE) in such regionally delineated pedagogical concepts did not occur in the past, since current pedagogical works do not comment on this theme (see note 1). The second selection criterion was based on the ideological essence of AAE - their association with humanism. Pedagogical concepts, with which empathy, acceptance and authenticity of the teacher are most connected, are based on the humanist ideal of education.

It is aimed in particular at developing the personality of the pupil, his or her character, leads to social feeling, respect and love to others. The beginnings of humanistic ideas within education in pedagogical theory are connected with to the onset of Renaissance humanism. Later, they are linked to the pedocentric tendencies that were at the heart of the pedagogical reformism at the beginning of the twentieth century.

Specific selected personalities of J. A. Comenius, J. I. Felbiger, J. F. Herbart, O. Chlup belong to the main and important representatives of the Central European humanist / reform oriented pedagogy in the Central European space, as it is mentioned in the literature (see, for example, [34]).

J. A. Comenius (1592-1670) is a prominent representative of the humanistic approach to the world, his school should be a "workshop of humanity". In Comenius literature Comenius is classified into the era of renaissance, humanism and reformation. There is no doubt that he was strongly influenced by the humanistic ideas [14]. Comenius found inspiration for his pedagogical work in domestic (eg J. Blahoslav) and foreign predecessors (eg E. Rotterdamský or L. Vives), also with his contemporaries from abroad (JV Andreae, W. Ratke [14, 15]).

The widening enlightenment brought with it the necessity to implement school reforms. Their practical expression was the General School Regulations of J. I. Felbiger (1724-1788) aiming at the compulsory education of children aged from six to twelve years.

J. F. Herbart (1776-1841) is perhaps one of the most influential representatives of the nineteenth-century pedagogical theory and, as Cipro states, herbatism inspired by Herbart prevailed in European and overseas pedagogy even in the twentieth century [16]. Kádner spoke of Herbart's humanistic thought, and he openly described Herbert as the successor and the accomplice of Pestalozzi's thoughts [17]. Chlup emphasized the humanistic accent of Herbart's concept [18].

O. Chlup himself (1875-1965) was one of the important representatives of pedagogical reformism in the late $1920 \mathrm{~s}$ in Czechoslovakia.

As key documents in our case we will consider the key works of selected pedagogical theoreticians, in which they presented their concepts: Comenius [19, 20, 21], Felbiger [22], Herbart [23], Chlup [24, 25].

In connection with the nature of the documents, there is a fundamental internal review of the documents - the content 
of the documents and their subsequent interpretation.

\subsection{Basis for Analysis and Interpretation}

The process of interpretation itself is often criticized for subjectivity. Here, according to Miovsky [12], we must state that "any more complex text can be analyzed and interpreted from different angles of view". In this context, it is important for the researcher to make his point of view explicit - to set out the starting points - the perspectives, the criteria by which the text will be judged [12].

Our analysis and interpretation of pedagogical concepts, our point of view will be focused on empathy, acceptance and authenticity of the teacher. To analyze selected documents, we have first defined the criteria for reviewing the text in advance. This is a review in terms of the occurrence of the discussion of empathy, the acceptance and authenticity of the teacher. Here we have focused on their essence and manifestations. This is also because, in older pedagogical theories, these terms do not exist.

Teacher's empathy (for more, see Section 1.) can be defined as understanding the pupil (s), understanding his or her views, experiences, problems that differ from his or her own. In addition, it includes the understanding of his or her emotions and the empathizing with the pupil. The most prominent manifestations of teacher's empathy include listening to the pupil connected with the interest in what he or she says. This is the so-called shown empathy, expressed in an attempt to understand the other. The manifestation of this understanding takes place in communication through active listening, so-called paraphrasing. Here the teacher repeats in his own words the basic idea the pupil tells him [26]. Next, of course, we focus on similar synonymous concepts, such as sympathy and empathizing, which were used instead of the concept of empathy.

Acceptance (from the Latin acceptus, kindly accepted, dear) is the acceptance of the other one as he or she is, with regard and respect (see Section 1.). As described by C. R. Rogers himself, this is essentially about the expression of Christian agape - love, which is also responsible, patient and caring [2]. Love, in the relationship between a teacher and a pupil, can also be called "pedagogical love." Part of this effort to understand the other is to create a positive emotional relationship towards the pupil, which is reflected in the teacher's positive attitude, kindness, friendliness, leniency, love towards the pupils, which should contribute to the creation of a favorable atmosphere in the educational process. Pedagogical love - acceptance, teacher's relation to the other - the pupil, we will therefore continue to consider it necessary, accompanying the component of teacher's empathy.

Next, we will focus on authenticity, veracity (see more in Section 1) for self-empathy, listening to oneself. Let us add that empathy itself and a positive attitude towards another must be based on genuine, authentic interest in the other. Within the situation, the teacher must be sufficiently congruent, authentic.

\section{Results}

\subsection{The Work of Comenius and Acceptance, Authenticity, Empathy (AAE)}

Comenius, in his education for humanity, emphasized the quality of the relationship between parent and child, teacher and pupil. He pointed out that education should be done with love and respect for the child's personality, which has to be recognized as best as possible. "Teachers, when they will be friendly and kind, will not repel the pupils with any roughness, but bring them to themselves by their fatherly mind ... in short, when they treat them with love, they will easily gain their hearts." [19]. He sought to make the teacher, based on this knowledge, adapt his or her interpretation to the level of abilities and understanding of pupils [14]. Also, in Comenius, "The Latest Method of Languages", we find that the teacher should be aware of the peculiarities of individual pupils: "let the teacher come down to the pupil and help his understanding in all possible ways ... the teacher does not teach as much as he can teach, but as many as the pupil can understand ... the soul of teaching is the adaptation of the teaching to the pupil's talents." [20, 27]. This is, according to Čapková, an exemplary example of a psychological empathizing of a teacher with a pupil, which aims to adapt the curriculum to a pupil: "Human nature is adapted so that ... all abilities seek adequate nutrition. If you deny it, they are sad, they fail, ... but if you do it too dense, then you are harming it ... there is a need for caution to properly provide the eye with light, and there will be everything in the light, whatever you want." [20, 27].

In his treatise on Comenius, Floss also mentions this. He talks about Comenius freedom and the nonviolence of teaching. That is to be adapted to the natural possibilities of the pupils. It certainly should not be mugging up, by mechanically pouring knowledge [28].

Comenius strongly emphasized the understanding of the curriculum. The pupil should not only remember the taught matter, he criticized the mere memorizing that was common in a number of schools at that time. Knowing everything in the sense of mastering the greatest possible amount of knowledge on the basis of mere memory did not become a goal, but all wisdom. It was about knowing what is essential, which was connected with the understanding of relations and the context between knowledge [29].

Achieving this qualitatively higher level of knowledge should be accomplished by a specific repetitive technique. This technique, in a number of aspects, corresponds to a model of empathy manifested through active listening. During the teaching, the teacher should periodically convince himself or herself of the level of understanding of the subject presented to his or her pupils. He first 
repeats himself, then lets from one to three pupils repeat aloud, then the pupils have to repeat quietly and finally again aloud [30]. In this paraphrasing of his or her interpretation by the pupils the teacher is convinced of how they understood the topic he had delivered. The technique of active listening that Comenius meant, approaches the most the so-called mirroring. Here, the pupil, in the words of a spokesman, repeats the essential parts of his or her message. There is a need for selectivity, work with information, not to repeat without understanding, just "parroting back". It is about choosing what the listener himself considers essential from the speaker's statement. Comenius also certainly did not mean "parroting back" because he was a great critic of memorizing, "... parrots who recite someone else's thoughts, not giving away anything that would cost anything" [27].

What does Comenius say about this: "... when a teacher of every class introduces this wonderful way of practicing among his disciples in this way: Each lesson he or she will shortly introduce the topic, clearly explain the meaning of words, and will obviously show the usefulness of things, then prompt one of the pupils to repeat in the same order everything the teacher said in order to clarify the rules in the same words and point to the same examples ... once he or she makes mistake he or she must be corrected. Then he will call another and will do the same ... then the third, the fourth and how many will be needed until it is obvious that all of them have understood and can do it again and properly teach ... The teacher learns more clearly if everyone understands what he has lectured." [19].

\subsection{Discussion to the Works of Comenius}

As we have already said, and it follows from all Comenius philosophy, there is no memorizing here, and "all" here, in our opinion, means everything essential from the topic. There was therefore a need for pupil selectivity in relation to the information transmitted. The emphasis on "the same words", in the words of a spokesperson, is in our view to enable pupils to acquire a conceptual device related to the presented topic, so it is the key concept of the subject (which, of course, he or she understands and can explain).

Other characteristics of a good teacher include: to be able to understand the pupils, to understand their abilities, their characteristics, and their individualities and accordingly to affect the pupil. What else can in this case help the teacher more than the ability of empathy? Empathy in this case is directly related to the teacher's love for pupils (element of acceptance), the interest for pupils (a possible element of authenticity, not explicitly expressed) through which the "pansofic personality" gradually forms in the pupils. Very inspiring is that empathy, active listening, is purposefully required from his or her pupils. Indeed, this two-way relationship is suggested, for example, in Didactics analytical "let the teacher and the pupil listen to each other." [21].

The work of Comenius was not very well known in our countries; his books were not published until the first half of the nineteenth century [31]. As Kadner further states, "It is truly incredible that all the promising beginnings and new thoughts became empty... In short, the merger of the Humanist and Reformational movement failed religiously, scientifically and nationally ... cultivating a single ability memory" [15]. We can say that there is a decline in education at that time, the advanced education from the time before Bílá Hora fell to the lowest level. Teaching was done through memorization and primitive imitation with slave discipline. The vast majority of folk masses could not read or write [15].

\subsection{Felbiger as the Successor of Comenius}

An important Felbiger's action was his methodical book, which was to become an organizational and didactic aid for the construction of the then Austrian educational system. It was first published in German (1775), and two years later it was translated into Czech. We will come out of its edition from 1824, which is written in the Gothic script. This work was an important aid for many generations of educators for many decades [32]. Felbiger attempted to address the key components of the educational process.

For our purposes, there is a key basic rule of teaching, set forth by Felbiger. It is a requirement for the teacher to build a positive attitude towards the pupils and to gain their trust. It emphasizes the teacher's love for all pupils, impartially regardless of their status. He encourages the teacher to "show them at every opportunity, in words, faces, all your behavior, that you love them with heart", teacher has to be gracious, friendly and kind [22]. This requirement, as stated by Uhlírová, for the personality characteristics of a teacher, which encourages him to kind and patient behavior towards pupils, has inspiration in Comenius's Great Didactics [33]. Thanks to a kind approach, a positive classroom climate is created, in which "teaching will be much easier" [22].

Of course, the interest in the pupil is part of this approach. The teacher should try to get to know the personality of his or her pupils [22], how they learn along with the degree of their understanding the topic [22]. In order to achieve this, the teacher has to observe pupils not only during the educational process, but also in non-teaching activities [22]. Understanding the pupils should consequently lead to an individual approach towards them "to treat them according to their diversity, for the children are different and the way of dealing with them must also be different" [22].

In the teaching itself, the teacher should try to bring the topic closer to his pupils, by explaining it. By repeating (not testing), to make sure they understoond it enough. Here he put emphasis on the dialogical method, through which a teacher can learn how a learner understands the 
topic. He emphasized the form of a teaching conversation, so-called "catechism", "a constant intercourse between the teacher and the pupils ... because it keeps the attention of the pupils and constantly employs their memory, leads the teacher to adapt the teaching according to the children's abilities, facilitates the observation, whether the students understood him or her and if not. " [22].

Of course, the introduction of Felbiger's ideas (or, as presented by Felbiger), in their fullness met with difficulties. The transition to mass teaching itself was a problem, as there was a great shortage of qualified teachers and textbooks. That is why teachers often taught only through interpretation and dictation [32]. Also, another Felbiger's recommendation remained misunderstood, or it was simplified to such a level that it lacked the original meaning. For example, Kadner points to the use of the tabular method [34], which has been reduced to mere formalism, mechanical repetition, dril [35, 36]. Despite these distortions, however, we can say that some of the ideas and practices have come into practice in Czech schools. Felbiger's contemporary and implementer of enlightenment reforms, F. Kindermann, also had a significant credit for it.

\subsection{Discussion to the Works of Felbiger}

Felbiger, like Comenius, stood up against the literal repetition - parroting "they never have to learn by heart things that they do not understand, for what they cannot understand can never have enough benefit" [22]. On the contrary, the teacher had to lead his disciples to express themselves in their own words [22].

At Felbiger, we have similarity with Comenius by using repetition of the teacher's words by pupils. The pupil repeats in his own words how he understood the teacher's interpretation. This way of repeating, however, Felbiger transformed into a system of questions through which the teacher verified the pupil's understanding of the subject. There is not preserved original Comenius model, when the recipient of the communication (the communicant), by mirroring, verified his or her understanding of the ideas from the communicator. The aforementioned General School Rules in $\S 44$ and $\S 45$, according to Felbiger's instructions, devoted the description of catechesis. Here it is stated that "catechesis is understood ... the answer by the pupils, when it is possible to know what the pupils think about the topic". [32]. It was during the catechetical inquiry that the teacher knew how the pupils understood him. He was able to identify any misunderstandings he could subsequently modify. In describing the teacher's responses to the pupil's answers, Felbiger, of course, did not concern himself with the teacher's verifying that he understood the pupil's interpretation. It would be illogical. It is just the pupils who have to express the teacher's understanding in this catechetical system and not the other way around. Felbiger further emphasized that the catechetical method should be aslo used in other subjects, not only in the teaching of religion [32].

\subsection{Herbart's Pedagogical Concept and AAE}

In Herbart's theory, the basic components of pedagogical action of a teacher on pupils are control and discipline. These are supposed to precede the teaching itself. Contrary to Rousseau's liberal style, Herbart considered it important first to control the children's anti-social instinct. Here is a need for a supervisor to learn the child to live and behave in the appropriate social system. The best means of control and discipline is the authority and love of the educator. Authority represents father, love then represents mother. At school, both of them have to be merged in the person of the teacher. The authority and the teacher's love towards the pupils are therefore some starting points for the performance of the teaching profession. [17, 23].

What specifically did Herbart think "by the teacher's love" (pedagogical love), let him show himself. Love "consists of a harmony of feelings and a habit ... the harmony of feelings of love that love requires can arise in two ways. Either the educator penetrates into the feelings of the pupil, and with all the softness, without talking about it, joins them, or cares for himself to become accessible to the common feelings with the pupi,l which is more difficult, but it must also be associated with the penetration into the feelings of the pupil. Only in this way the pupil can bring his or her own power into the relationship when he or she has the possibility to have something in common with the educator in some way" [23].

Empathy is also close to the "emotional involvement" that he deals with in the course of teaching. This involvement is manifested in interpersonal contact "we can also spread contact and absorb the mind into the individual components of the emotional involvement that the contact prepares ... because the overall feeling to one person, finally to the whole circle of persons, is always composed of many individual feelings - and from feelings to others, the feelings for others must first be carefully highlighted, that egoism unnoticed does not suppress participation " [23]. Through this emotional involvement, the intensity of contact can be increased, mutual relations deepened, pedagogic love deepened.

Let us remind that Herbart emphasized the teacher's respect for the pupil's individuality. In his opinion, the educator should carefully study his pupils and then adapt his educational measures to their individualities [17].

Empathy of a teacher, as a central component of Herbart's pedagogical love, is precisely the means that can create the teacher-pupil reconciliation as well as reveal the psychic focus of the educator to the child [23]. This reconciliation and the pedagogical love based on it must be deepened by the educator as it forms the basis of the educational process. Empathy, through pedagogical love along with the knowledge framework, co-creates the 
so-called pedagogical tact, which is a sort of "bolt" between pedagogical theory and practice. This pedagogical tact, which Herbart defined as quick judgment and decision-making, is being developed and perfected in pedagogical work. Thanks to the pedagogical tact, the teacher can adapt the generally conceived theory to the individual case of practice, the individuality of the pupil [23].

The rise of Herbart's teachings took place in the second half of the nineteenth century in the form of herbartism, and in Germany at that time it became an official pedagogical stream. Of course, Herbart's teachings and herbartism cannot be identified, as Herbart's successors interpreted their source in a different way. The quest for quantification and assurance of results led to formalism, schematism, materiocentrism. In this herbart's so-called pedeutological model, the pupil became a passive element, the object of a targeted and continuous teacher's work.

Thanks to the reduction and adaptation (where especially T. Ziller's stream dominated), the lesson focused only on the curriculum itself. Instead of teaching, they focused on mere positive knowledge, the teaching of thinking. This "Zillerian Herbartism" spread throughout Germany, the US and Scandinavia, and in the second half of the nineteenth century it became the official pedagogical philosophy of Austria (Austria-Hungary) [17].

It was this simplification, the absence of an individual approach to pupils based on pedagogical tact and pedagogical love lacking teacher empathy that led to the reform of the pedagogical movement at the beginning of the twentieth century (see, for example [17, 23, 34]).

\subsection{Discussion to the Works of Herbart}

Based on the above example we can say that teacher empathy forms the central element of pedagogical love, which, together with the teacher's authority, is the basis of his or her pedagogical work. Herbart, in his definition of love, clearly spoke of the teacher's empathy towards the pupil (the educator penetrates into the feelings of the pupil) wanted to achieve a "harmony of feelings". Since Herbart mentioned a harmony of feelings, we think that here he thinks what we call affective empathy today, feeling a second person's psyche and emotionally sharing the feelings of the pupil.

However, the harmony of feelings can be achieved in a different way. This may be a manifestation of the teacher's self-empathy (he or she makes sure that he or she becomes accessible to his or her common feelings with the pupil) even when the educator is trying to feel empathetic (but it must also be associated with penetration into the feelings of the pupil). Herbart, in our opinion, through the manifestation of self-empathy (verbalizing our own feelings - "I say"), seeks to bring his world closer to the pupil so that the pupil approaches the teacher and their relationship is strengthened.

\subsection{The Chlup's Theory in Relation to AAE}

Chlup, like other educators of that time, was aware of the deficiencies of Herbart's approach. In particular, it was his over-intellectualism, which is insufficient for the educational activities of the school. He saw the correction of this state in deeper recognition of the pupil-child, later sought solutions in a positivist approach, in his scientific foundations [37].

It is important for our intent that, in addition to the subject matter of the basic curriculum, Chlup dealt with the relationship between the teacher and pupils, the trueness of the teacher and the principles of cooperation between the teacher and the pupils [37]. Chlup devoted himself to this theme in his Secondary School Didactics. He reflected the need to change the teacher's approach to pupils as a result of the need to implement reforms in the educational process. The teacher should initiate more active and independent activities of pupils, should be a guide rather than a mentor, today we would call it the facilitator.

The essential element of the teacher's activity was to teach his pupils to learn, to think, to work with facts, concepts, to draw conclusions. Chlup emphasized the principle of cooperation, mutual cooperation between teacher and pupils in the learning process, with teacher as a facilitator. So the teacher gains a new important position in the teaching process. The barrier between the teachers and the pupils that had been here in the past broke. Chlup talked about the ending teacher's authoritarianism and dictatorship, followed by democratic tendencies, sharing knowledge [24].

In his lecture The Principles of Work in Education, where he was thinking about teaching methods in facilitation of pupil cognitive processes, he pointed out the necessity to revise the existing teaching procedures. In the context of the "breaking of barriers" between the student and the teacher, he used the example of Socrates, who "felt in the spirit of the man who was at the beginning of his problem, and in this way he succeeded in bringing the uneducated spirit to understanding of the deep truths" [25]. Chlup here directly indicates the possible way of creative work with the pupils. It means to understand the current thinking state of the pupil and to work with him further on this basis.

Chlup dealt with the teacher's understanding of the pupil also in the context of pupil's personality development. He referred to E. Spranger, who spoke of the necessity of understanding, "identifying or empathizing the sense of behavior ... with the help of his own experiences ... he sees the noetic tool of knowing the youth" [24] that a young person needs at a given age probably the most. Certain confirmation of similarity with Rogers's model of teacher skills is given to us by Chlup himself. He speaks of the fact that the image of a teacher's personality "if it was built on machine-made speeches that do not fully derive from the entire personality of the teacher,...autocritics,... intellectual and moral truthfulness, righteousness, 
consistency and thoughtfulness ... are qualities effective and enthralling to imitate" [24]. Chlup here talked about the truth of the teacher, his authenticity to be what he really is before the pupils. This authenticity is directly related to self-awareness, self-empathy, autocritics mentioned in the quote.

Kindness to the pupil can be combined with Rogers's acceptance of the other, that is to have respect for the other, to treat him in a respectful way - especially in connection with authenticity (to be authentic but at the same time considerate).

\subsection{Discussion to the Works of Chlup}

We believe that Chlup's "breaking the barriers" between the teacher and the pupil opens the room for the empathic skills of the teacher. In order for the teacher to be able to properly help his or her pupils in what they really need, he or she should be able to understand them, understand their thought processes, current mental states. We think that really effective facilitation is not possible without understanding others. In the above-mentioned characteristic of a teacher, as a pupil's helper, who cooperates with pupils and tries to develop pupil's thinking, we can find some features of the teacher's personality, which are also in Rogers's human education (authenticity, acceptance and empathy).

Of course, it only relates to the characteristics of the teacher, not to Rogers's whole concept of education focused on human beings. Chlup would certainly not agree, for example, with Rogers's idea that learning content is a secondary element.

Chlup became a promoter of the "New Schools" movement, but practically experimented (in addition to experimental teaching the mother tongue) and devoted rather to the theoretical critical assessment of foreign pedagogical experiences [38].

\section{Conclusions}

We believe that Comenius made a significant contribution to shaping the teacher's positive attitude toward the pupils, which should be based on empathy with elements of acceptance and authenticity. Without it, it would not be possible to attain the Comenius concept of the school as a workshop of humanity. Although Comenius, or even his closest, do not explicitly state this concept, it is clear from his work that their own content - approaching, understanding and listening to the pupil, love to the pupil, interest in the pupil were one of the key elements of his educational conception. Comenius stressed that without the ability to understand pupils, it is not possible to effectively shape their personality. It may also be essential to use active listening by pupils, manifested empathy, to improve their learning outcomes.
In his pedagogical concept, Felbiger sought to create a positive relationship between teacher and pupil, to gain mutual trust. This is not possible without the teacher's kind approach to individual pupils, which is connected with the attempt to understand the pupil, the knowledge of his personality, and the way the pupil could understand the discussed topic. In order to understand pupils' thoughts, he recommends a dialogical (catechetical) teaching method in which pupils can present their views on a given problem, discussed topic. On the basis of this knowledge, in case of the pupil's misunderstanding, the teacher then has to adapt his or her teaching process.

In the works of Felbiger, we find the overall modified Comenius approach of the teacher to the pupil. There is still a tendency of a kindly approach to pupils, a love for the pupil (element of acceptance), the area of knowing the personality of the pupil (interest for the pupil, without explicit authenticity) and the discovery of his or her views through catechesis is then more elaborated.

Here we can see a shift away from Comenius' technique of active listening to pupils. Felbiger focused only on creating a questioning system by which the teacher verifies the pupil's understanding. Following the procedure, where the communicator sends a message to a communicant who verifies his or her understanding by mirroring, is missing here. In accordance with Comenius, understanding should not be based on memorizing but on a deeper understanding of the topic presented.

Empathy of a teacher, as a central component of Herbart's pedagogical love, is precisely the means that can create a harmony between the teacher and the pupil and uncover the child even the mental focus of the educator [23]. This harmony and the pedagogical love (the element of acceptance) based on it must be deepened by the educator as it forms the basis of the educational process. Empathy, through pedagogical love along with the knowledge frame, co-creates the so-called pedagogical tact, which is a sort of "bolt" between pedagogical theory and practice. This pedagogical tact, which Herbart defined as quick judgment and decision-making, is developed and perfected in pedagogical work. Thanks to the pedagogical tact, the teacher is able to modify a generally conceived theory on a particular case of practice, on the individuality of the pupil [23].

Chlup in his concept brings a picture of a teacher - a facilitator who has some features of teacher of Roger's pupil-oriented education. Based on the analysis of the texts, we tried to show that Chlup's teacher should use empathy, he or she should also be authentic and show some form of acceptance towards the pupil. In addition, Chlup also contemplated the possibilities of increasing empathy among pupils, in connection with the development of imagination. It is necessary to appreciate his approach to teacher education, which should be based on both theoretical knowledge and the development of practical skills. 
We have to say that the results of the work brought many surprises to the author. The biggest findings were related to the first two research questions. Interesting findings have already been provided by the analysis of Comenius pedagogical concept.

Approaching the pupil, trying to understand him or her, interest in the pupil was the basis of his concept of school as a workshop of humanity. In addition, description of a specific repetitive technique for school teaching, which carries features of much later realized so-called active listening, can be found at Comenius. Empathy and teacher acceptance, according to this thinker, should make a significant contribution to 1) shaping the personality of the pupil, 2) improving the educational process (also Comenius "active listening" should bring better educational results). These two lines, opened by Comenius, the contribution of empathy and teacher acceptance pedagogical and educational - were only repeated or even deepened in other pedagogical concepts.

In all of the pedagogical concepts analyzed, empathy, acceptance (and even authenticity) of the teacher had a significant place. Although these thinkers did not elaborate them in detail, they were aware of their value, or the importance of what they could bring in school practice. The rationale for their importance for the educational process was in two indicated lines, which were mutually interrelated among the authors.

The conclusion of the concept of teacher empathy, acceptance and authenticity in pedagogical theory was brought by PCE. From this point of view, this, at the same time, most closely related the sophisticated psychological conception of empathy, in Rogers's case, the emotionally cognitive concept of empathy, with a pedagogically focused theory. The paper tried to prove that Rogers was not the first and not the only one to deal with the teacher's approach to pupils based on humanity. A very positive finding for us is that Rogers, equipped with a much richer conceptual apparatus and research methods, in the issue of the humanist approach of the teacher to the pupil, came to very similar conclusions as his predecessors. It may indicate the fact that the humanist approach to the other one creates (can create), a positive relationship (between a teacher and a student or a psychotherapist and a client) can be based on certain essential elements - here AAE. We believe that in order to move forward in pedagogy in this area, we should carefully "look back", as our predecessors dealt with it, learn from mistakes and mistakes. We can continue in the "interrupted" steps and procedures to find here the necessary inspiration to solve the current problems of the present.

\section{REFERENCES}

[1] L. Nykl. Carl Ransom Rogers a jeho teorie: prrístup zaměřený na člověka, Grada, Praha, 2012.

[2] J. Vymětal. Rogersovská psychoterapie, Český spisovatel, Praha, 1996.

[3] J. Skalková. Humanizace vzdělávání a výchovy jako soudobý pedagogický problém, Univerzita Jana Evangelisty Purkyně, Ústí nad Labem, 1993.

[4] Y. Bertrand. Soudobé teorie vzdělávání, Portál, Praha, 1998.

[5] D. Šiffelová. Rogersovská psychoterapie pro 21. století: vybraná témata z historie a současnosti, Grada, Praha, 2010.

[6] F. Singule. Současné pedagogické směry a jejich psychologické souvislosti, SPN, Praha, 1992.

[7] C. R. Rogers. Způsob bytí: klíčová témata humanistické psychologie z pohledu jejího zakladatele, Portál, Praha, 1998.

[8] C. R. Rogers. Být sám sebou, Portál, Praha, 2015.

[9] C. R. Rogers, H. Freiberg, Sloboda učit' sa. Persona, Modra, 1998.

[10] R. Motschnig, L. Nykl. Komunikace zaměřená na člověka: rozumět sobě i druhým, Grada, Praha, 2011.

[11] J. Hendl. Kvalitativní výzkum, Portál, Praha, 2005.

[12] M. Miovský. Kvalitativní př́stup a metody v psychologickém výzkumu, Grada Publishing, Praha, 2006.

[13] P. Mayring. Einführung in die qualitative Sozialforschung. Eine Anleitung zu qualitativem Denken, Psychologie Verlags Union, Weinheim, 2002.

[14] D. Čapková. Myslitelsko-vychovatelský odkaz J. A. Komenského, Academia, Praha, 1987.

[15] O. Kádner. Dějiny pedagogiky II., Unie, Praha, 1923.

[16] M. Cipro. Němečtí pedagogové. Cipro, Praha, 2003.

[17] O. Kádner. Dějiny pedagogiky III., Unie, Praha, 1923.

[18] O. Chlup. Vývoj pedagogických idejí v novém věku, FF, Brno, 1925.

[19] J. A. Komenský. Didaktika velká, Komenium, Brno, 1948.

[20] J. A. Komenský. Vybrané spisy J. A. Komenského, SPN, Praha, 1964.

[21] J. A. Komenský. Analytická didaktika, SN, Praha, 1947.

[22] J. I. Felbiger. Kniha methodnj nebo Nawedenj k dokonalému wedenj včitelského vřadu pro včitele na triwialnjch a hlawnjch sskolách, Kronberg a Weber, Praha, 1824.

[23] J. F. Herbart. J. F. Herbart a jeho pedagogika, SPN, Praha, 1977.

[24] O. Chlup. Středoškolská didaktika, Společnost nových škol, Brno, 1935.

[25] O. Chlup. K základním otázkám pedagogiky: výbor z díla, SPN, Praha, 1957.

[26] J. Čáp, J. Mareš. Psychologie pro učitele, Portál, Praha, 2001. 
[27] D. Čapková. J. A. Komenský, projektant nápravy věcí lidských, Aleko, Ostrava, 1992.

[28] P. Floss. Nástin života, díla a myšlení J. A. Komenského, Vlastivědný ústav, Přerov, 1971.

[29] D. Čapková. Některé základní principy pedagogického myšlení J. A. Komenského, Academia, Praha, 1977.

[30] J. Kopecký et al. Jan Amos Komenský: nástin života a díla, SPN, Praha, 1957.

[31] J. Váňa. Dějiny pedagogiky, SPN, Praha, 1963.

[32] V. Štverák, J. Mrzena. Felbiger a Kindermann-reformátoři lidového školství, SPN, Praha, 1986.

[33] J. Uhlířová. Česká východiska rakousko-uherského školství,
Všeobecné vzdělávání pro všechny, mezinárodní conference, Pedagogické muzeum J.A. Komenského, Praha, 107-117, 2004.

[34] T. Kasper, D. Kasperová. Dějiny pedagogiky, Grada, Praha, 2008.

[35] O. Kádner. Dějiny pedagogiky II., Unie, Praha, 1923a.

[36] R. Vlha. Felbigerova kniha metodní, Didaktické studie, Vol. 5, No. 1, 46-53.

[37] O. Chlup, V. Pařízek. Otokar Chlup a perspektivy výchovy, SPN, Praha, 1977.

[38] K. Rýdl. Alternativní pedagogické hnutí v současné společnosti, M. Zeman, Brno, 1994.

*This article was written by modifying and expanding the text Forgotten Concepts of Teacher - Inspiration for Today Comenius and Felbiger. In MAGNANIMITAS. Sapere Aude 2015, Koncepty dneška, vol. V. Hradec Králové: MAGNANIMITAS, 2015. p. 234-240, ISBN 978-80-87952-09-2. 